\title{
Sire Influence on Juniper Consumption by Goats
}

\author{
Chad R. Ellis, ${ }^{1}$ Royce E. Jones, ${ }^{2}$ Cody B. Scott, ${ }^{3}$ \\ Charles A. Taylor, Jr., ${ }^{4}$ John W. Walker, ${ }^{5}$ and Dan F. Waldron ${ }^{6}$ \\ Authors are ${ }^{1}$ former graduate student, ${ }^{2}$ former graduate student (deceased), and ${ }^{3}$ Associate Professor, Angelo State University, \\ San Angelo, TX 76909; ${ }^{4}$ Professor, Texas Agricultural Experiment Station, Sonora, TX 76950; ${ }^{5}$ Resident Director of Research \\ and Professor, and ${ }^{6}$ Professor, Texas Agricultural Experiment Station, San Angelo, TX 76901.
}

\begin{abstract}
Goats avoid eating redberry juniper (Juniperus pinchottii Sudw.) when other palatable forages are available but will increase intake of juniper when exposed to the plant for several days. Intake of redberry juniper also differs among breeds and individual goats. Selection based on foraging habits could further improve juniper intake. The purpose of this study was to determine the influence of sires on juniper consumption. Heritability of redberry juniper intake was assessed for 3 years (1997, 1998, 2000) by placing male Boer-Spanish cross goats from 4-8 sires (the number of sires differed among years) in individual pens and feeding juniper ( $200 \mathrm{~g}$ ) daily for 2 hours over 5 to 10 days. Feeding juniper was done after weaning kid goats each year. Juniper intake was similar among sire groups within years. Heritability of juniper consumption was low $(11 \%)$ across the 3 years of this study. Goats increased juniper intake daily while in individual pens. These results suggest that an acceptance of juniper by goats can be conditioned through exposure to the plant after weaning, and that juniper consumption does not appear to be a highly heritable trait.
\end{abstract}

\section{Resumen}

Las cabras evitan comer "Redberry juniper" (Juniperus pinchottii Sudw.) cuando otros forrajes más apetecibles están disponibles, pero incrementan el consumo de "juniper" cuando están expuestas a él por varios días. El consumo de "Redberry juniper" también varia entre razas y cabras individuales. La selección basada en los hábitos de forrajeo pudiera mejorar más el consumo de “juniper”. El propósito de este estudio fue determinar la influencia del padre en el consumo del "juniper”. La heredabilidad del consumo de "Redberry juniper" fue evaluado por 3 años (1997, 1998 y 2000) colocando machos cruzados de Boer-Spanish (provenientes de 4-8 padres y el número de padres difirió entre años), en corrales individuales y alimentándolos con “juniper” (200 g) diariamente por 2 h durante 5 a 10 días. La alimentación con "juniper” fue hecha después de destetar los cabritos cada año. El consumo de "juniper" fue similar entre grupos de padres dentro de años. La heredabilidad del consumo de "juniper" fue baja $(11 \%)$ a través de los tres años del estudio. Las cabras incrementaron el consumo diario de "juniper” mientras estuvieron en los corrales individuales. Estos resultados sugieren que una aceptación del "juniper” por las cabras puede ser condicionada a través de la exposición a la planta después del destete, y que el consumo de "juniper" no parece ser una característica de alta heredabilidad.

Key Words: Juniperus, heritability, intake, feedback, terpenoids

\section{INTRODUCTION}

Redberry (Juniperus pinchotii Sudw.) juniper has increased across western and central Texas over the past 100 years (Ansley et al. 1995). Suppression of fire, periodic drought, and overgrazing have contributed to the expansion of juniper throughout the Edwards Plateau and Rolling Plains of Texas (Ellis and Schuster 1968; Archer 1994). In addition, juniper cover has probably increased because domestic ruminants avoid eating juniper because of terpenoid levels that reduce palatability (Riddle et al. 1996; Pritz et al. 1997).

As juniper density increases, forage production decreases (Dye et al. 1995). Most ranchers implement some type of juniper

Research reported herein was supported by University Lands, Midland, Texas; Management, Instruction, and Research Center, San Angelo, Texas; and the Texas Agricultural Experiment Station, College Station, Texas.

Correspondence: Cody Scott, Box 10888, ASU Station, San Angelo, TX 76909. Email: Cody.Scott@angelo.edu

Manuscript received 3 October 2003; manuscript accepted 14 November 2005 control, including prescribed burning, mechanical removal, and herbicides. Mechanical removal and herbicides are not economically feasible in many cases (Johnson et al. 1999). Prescribed burning can be effective in controlling ashe juniper (Bryant et al. 1983; Steuter and Britton 1983), but redberry juniper resprouts after topkill from burning (Rasmussen and Wright 1989).

Goats may consume juniper, but intake is limited because of terpenoid levels that kill rumen bacteria when intake exceeds $30 \%$ of the diet (Straka et al. 2003). Observational data suggest that intake typically ranges from $0 \%-13 \%$ when goats are foraging on pasture (Bryant 1977; Nelle 1997). In previous studies, goats increased juniper intake (e.g., 50 to $200 \mathrm{~g}$ during 2-hour daily feeding events) over 10 days of exposure apparently because of physiological adaptation to terpenoids (Bisson et al. 2001).

This study assessed the heritability of juniper consumption by goats. Intake data were collected for 3 years from offspring from unrelated sires (unrelated within each year). Preference for some unpalatable and toxic plants can be influenced by genetic selection. For example, the heritability of big sagebrush (Artemisia tridentata Nutt.) consumption is moderately high 
$\left(H^{2}=.29\right)$ (Snowder et al. 2001). Similarly, the genotype of sires appears to affect consumption of other poisonous plants like bitterweed (Hymenoxys odorata DC.) (Frost et al. 2003).

\section{METHODS}

This study was conducted for 3 years $(1997,1998,2000)$ at the Texas A\&M Agricultural Experiment Station, located between Sonora and Rocksprings, Texas (lat $30^{\circ} 16^{\prime} 00.3^{\prime \prime} \mathrm{N}$, long $\left.100^{\circ} 33^{\prime} 55.9^{\prime \prime} \mathrm{W}\right)$. In 1997, 65 Boer-Spanish cross goats from 8 sires were used. Thirty-three Boer-Spanish cross goats from 4 sires were used in 1998. In 2000, 71 Boer-Spanish cross goats from 6 sires were used. The sires used in 2000 were the 3 highest and the 3 lowest juniper-eating goats from the 1998 feeding trial. Sires used in 1997 and 1998 were randomly selected from a commercial goat flock managed for meat production.

Each year, freshly weaned noncastrated male goats (age 5 months, weighing approximately $30 \mathrm{~kg}$ ) naive to juniper were placed in individual pens. Fresh water and calcium/phosphorous mineral with trace elements were provided ad libitum to all goats. In addition, alfalfa pellets $(1.5 \%$ body weight $[\mathrm{BW}])$ were fed daily to meet maintenance requirements (NRC 1981). Alfalfa pellets were available to goats immediately after feeding juniper (1000 hours) and until juniper was fed the next day (0800 hours).

Juniper intake was measured for a 2-hour period each morning. Between 0800 and 1000 hours, all goats were offered $200 \mathrm{~g}$ of redberry juniper foliage from both male and female plants. If, during the course of a feeding trial, an individual goat consumed all $200 \mathrm{~g}$, additional juniper was fed.

Juniper branches were clipped daily from mature trees, and leaves were stripped from the stems and fed. Refusals (orts) were collected and weighed to determine juniper intake. Additional samples were placed out of reach of goats in similar feeding troughs to account for moisture change during the feeding trial. Refusals were placed in an oven and dried at $60^{\circ} \mathrm{C}$ for 48 hours to determine dry matter content.

Juniper intake was measured for 10 days in 1997 and 1998 to estimate heritability of juniper intake. Juniper was not fed to goats in 1999 because offspring from sires were allocated to another unrelated study. In 2000, only one 5-day feeding trial was conducted because daily juniper intake was similar from day 5 through day 10 in 1997 and 1998.

To determine the influence of sires on consumption of juniper by their offspring, two separate analyses were performed. The first compared daily intake ( $\left.\mathrm{g} \mathrm{kg}^{-1} \mathrm{BW}\right)$ among offspring from different sires within years and between 1997 and 1998. Intake was analyzed using a repeated-measures analysis (day as the repeated measure) for the fixed effects of sires and year. Goats (replications) were nested with sires and years. Data from 2000 was analyzed separately using the same model without a year effect because of unequal variances. Means were separated using LSD when $P<0.05$. The statistical package JMP was used for this analysis (SAS 1998).

The second analysis estimated the amount of genetic variance and heritability both within and across years on the basis of juniper intake on the last day of feeding. The PROC
MIXED model of SAS was used, which included a linear covariate for body weight and a random effect for sire from which variance estimates were obtained. The heritability estimate (i.e., similarities among goats accounted for through genetic similarities) was calculated as 4 times the sire variance divided by the phenotypic variance. The phenotypic variance was the sum of the sire variance and the residual variance (Griffiths et al. 1999).

The 6 sires used in the 2000 trial were offspring from the 1998 trial. Sires were selected on the basis of their average juniper intake in 1998. The 3 goats that ate the most juniper and the 3 goats that ate the least juniper were selected as sires. Thus, the 2000 trial included a treatment effect based on divergent selection for juniper consumption. For this analysis, goats were nested within treatments (sires' consumption of juniper in 1998; most vs. least) and served as replications. Data were analyzed using a repeated-measures analysis because intake data was collected over 5 days of feeding (SAS 1998).

Sires were fed juniper for 10 days in 2000 to determine intake. Their juniper intake from 1998 was compared to their intake in 2000 using a repeated-measures analysis of variance (day as the repeated measure) (SAS 1998).

\section{RESULTS}

\section{Heritability of Juniper Consumption}

Goats readily consumed redberry juniper and increased $(P<0.05)$ intake over time throughout the 1997, 1998, and 2000 feeding trials (Fig. 1). Intake typically increased until day 5 during each year. In both 1997 and 1998, intake decreased on day 6 , followed by an increase in intake up to levels near the level on day 5 . When intake data were summarized across days of feeding in 1997 and 1998, juniper intake was lower on days 1-5 than on days 6-10 for all groups of offspring except offspring from one sire (Table 1). The offspring from sire number 4 decreased consumption of juniper in the second 5 days of feeding in 1997.

Intake differed $(P<0.05)$ between 1997 and 1998. Offspring in 1997 consumed an average of $1.9 \mathrm{~g} \mathrm{~kg}^{-1} \mathrm{BW}$, whereas in 1998 the average intake was $3.3 \mathrm{~g} \mathrm{~kg}^{-1} \mathrm{BW}$. However, within each of the 3 years, intake for groups of offspring was similar $(P>0.05)$, indicating that sires were not influencing juniper intake of their offspring.

Heritability estimates were calculated for each sire on the basis of his offspring's juniper consumption on the last day of feeding for each year (Table 2). The heritability estimates $\left(H^{2}\right)$ for 1997 and 1998 were 0 . In 2000, $H^{2}$ was 0.46. When heritability was calculated across years on the basis of individual goat intake on the last day of feeding, heritability was low $\left(H^{2}=0.11\right)$.

Six male offspring from 1998 were selected and used as sires for the 2000 kid crop. The 3 goats that ate the most juniper (Treatment 1 ) and the 3 that ate the least juniper (Treatment 2) were selected as sires. When intake was compared between years, sires consumed the same $(P>0.05)$ amount of juniper in 2000 as in 1998 (Table 3).

Intake was similar among offspring from different sires in the 2000 trial (Table 1). The treatment effect (sires' acceptance 

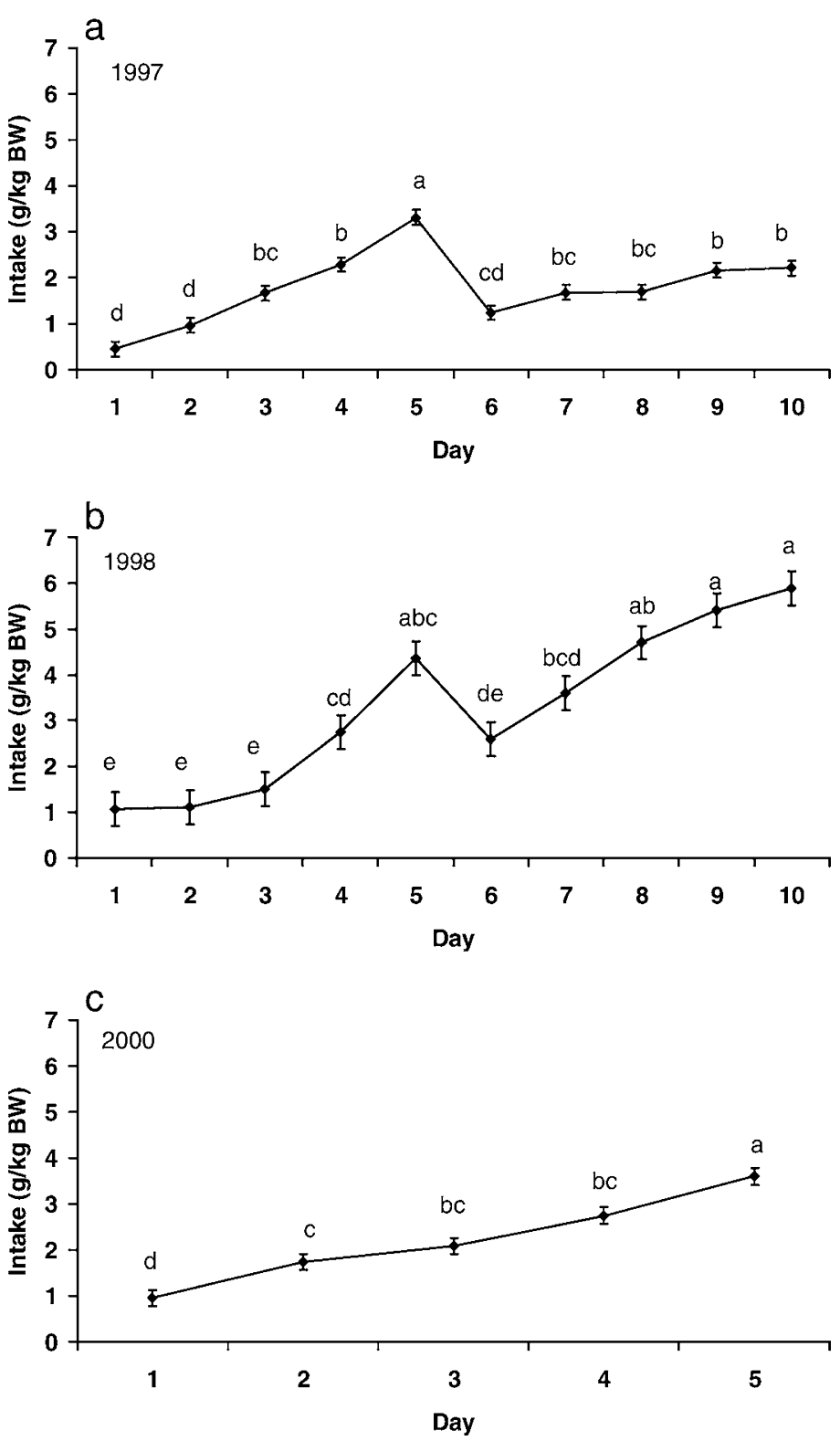

Figure 1. Intake $\left(\mathrm{g} \mathrm{kg}^{-1} \mathrm{BW}\right)$ of redberry juniper when goats were offered juniper for 2 hours daily in individual pens. Means with the same letters did not differ $(P>0.05)$.

of juniper) was similar (2.5 vs. 2.0 SEM $=0.2)$, but the treatment by day effect differed $(P<0.05)$ (Fig. 2). By day 3, offspring from sires that had eaten the most juniper in 1998 consumed more juniper than offspring from sires that had eaten the least juniper.

\section{DISCUSSION}

\section{Heritability of Juniper Consumption}

Undoubtedly, genes play an important role in physiological mechanisms affecting food preferences and detoxification of chemicals (Walker 1995). Although this study showed little evidence that consumption of redberry juniper was affected by sires (i.e., sire effect was similar within years; intake was not highly heritable), it does not negate other studies that have
Table 1. Dry matter intake $\left(\mathrm{g} \mathrm{kg}^{-1} \mathrm{BW}\right)$ of redberry juniper among each sire group averaged across days of feeding in 1997, 1998, and in 2000. Data from each year were analyzed separately because of unequal variances.

\begin{tabular}{rrrrrcr}
\hline & & \multicolumn{3}{c}{ Days of Feeding } & & \\
\cline { 4 - 5 } Sire & Year & $N$ & 37990 & 38116 & Sire Effect & SEM \\
\hline 1 & 1997 & 8 & 1.6 & 1.9 & 1.7 & 0.14 \\
2 & & 8 & 1.6 & 1.8 & 1.6 & 0.15 \\
3 & & 11 & 1.9 & 1.9 & 1.9 & 0.13 \\
4 & & 7 & 3 & 2.1 & 2.6 & 0.26 \\
5 & & 7 & 1.4 & 1.5 & 1.3 & 0.16 \\
6 & & 7 & 1.7 & 2.3 & 2 & 0.19 \\
7 & & 8 & 1.5 & 1.5 & 1.5 & 0.13 \\
8 & & 9 & 1.4 & 1.6 & 1.5 & 0.16 \\
9 & 1998 & 10 & 2.4 & 3.4 & 3 & 0.24 \\
10 & & 9 & 2.7 & 5.1 & 3.9 & 0.29 \\
11 & & 5 & 1.9 & 4.6 & 3.3 & 0.34 \\
12 & & 9 & 1.6 & 4.6 & 3.1 & 0.31 \\
13 & 2000 & 12 & & & 2.7 & 0.25 \\
14 & & 12 & & & 2.6 & 0.29 \\
15 & & 12 & & & 1.8 & 0.13 \\
16 & & 12 & & & 2.5 & 0.23 \\
17 & & 12 & & & 1.7 & 0.16 \\
18 & & 11 & & & 2 & 0.24 \\
\hline
\end{tabular}

demonstrated such a relationship with other plant species. A 2-year study conducted by Snowder et al. (2001) estimated the heritability of the percentage of mountain big sagebrush consumed in the diets of sheep. The study used 549 ewes originating from 100 sires. Heritability of the consumption of mountain big sagebrush was estimated at $H^{2}=0.28$. Warren et al. (1983) conducted a 2-year study on the heritability of diet

Table 2. Ending day dry matter intake $\left(\mathrm{g} \mathrm{kg}^{-1} \mathrm{BW}\right)$ of redberry juniper among each sire group in 1997, 1998, and in 2000. Heritability $\left(H^{2}\right)$ across all 3 years was 0.11 .

\begin{tabular}{ccccl}
\hline Sire & Year & $H^{2}$ & Sire Effect & SEM \\
\hline 1 & 1997 & 10 & 2.2 & 0.4 \\
2 & & & 2 & 0.46 \\
3 & & & 2.4 & 0.4 \\
4 & & & 2.9 & 0.52 \\
5 & & & 1.8 & 0.61 \\
6 & & & 2.6 & 0.39 \\
7 & & & 1.9 & 0.29 \\
8 & & & 1.9 & 0.66 \\
9 & 1998 & 0 & 5 & 0.86 \\
10 & & & 6.5 & 0.61 \\
11 & & & 6.7 & 1.28 \\
12 & & & 5.7 & 1.13 \\
13 & 2000 & 0.46 & 2.5 & 0.2 \\
14 & & & 4 & 0.53 \\
15 & & & 4.3 & 0.32 \\
16 & & & 4.6 & 0.77 \\
17 & & & 2.9 & 0.44 \\
18 & & & 3.4 & 0.57 \\
\hline
\end{tabular}


$\rightarrow-$ Sires that ate the most juniper $\rightarrow-$ Sires that ate the least juniper

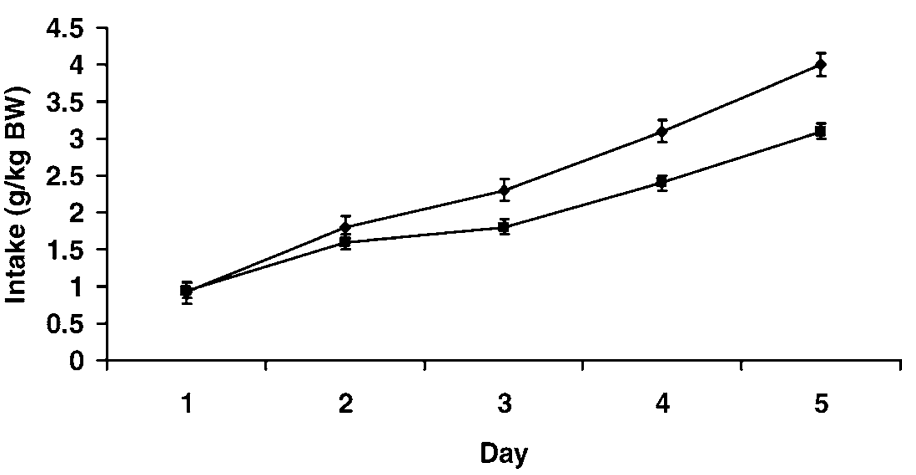

Figure 2. Intake $\left(\mathrm{g} \mathrm{kg}^{-1} \mathrm{BW}\right)$ of redberry juniper when goats were offered juniper for 2 hours daily in individual pens in 2000. The treatment $\times$ day effect differed $(P<0.05)$. Means with the same letters did not differ $(P>0.05)$.

selection of Spanish goats based on half-sib analysis of 155 goats from 14 sire groups. The average heritability of nonpreferred species was $H^{2}=0.30$. Mountain big sagebrush and juniper are both nonpreferred forages. Unlike Snowder's study $\left(H^{2}=0.28\right)$ and Warren's study $\left(H^{2}=0.30\right)$ showing high heritability index for nonpreferred forages, this study showed to have little sire effect ( $H^{2}=0$ within 1997 and 1998; $H^{2}=0.11$ across years).

The heritability estimate for 2000 was high $\left(H^{2}=0.46\right)$. The higher estimates in 2000 may have resulted because of the shorter collection period (5 vs. 10 days). The 2000 study also relied on divergent selection of sires on the basis of their acceptance of juniper rather than random selection of sires. Thus, sires' ability to consume juniper may have affected their offspring's juniper intake in the 2000 study. When offspring are reared in the same environment, divergent selection studies can be utilized to determine the impact of genetic selection. These studies are usually repeated over several years before accurate predictions regarding genetic selection can be made. Although divergent selection affected juniper intake in the 2000 trial, these results should be viewed with caution given there is only 1 year of data collection.

Intake differed across the 3 years of this study. Terpenoid levels vary seasonally (Riddle et al. 1996; Owens et al. 1998) and may differ from year to year, resulting in the differences in intake observed in this study.

Early life dietary experiences are important for future dietary habits in ruminants (Distel and Provenza 1991; Walker et al. 1992; Olson et al. 1996). Neurological, physiological, and morphological processes are susceptible to change in immature animals and can be modified so that they enhance their foraging skills and preferences (Provenza 1995). Sheep exposed to certain foods early in life often exhibit a preference for poor-quality and toxic forage (Distel et al. 1996). For instance, leafy spurge intake by yearling lambs was increased initially by exposure to the plant during weaning (Walker et al. 1992; Olson et al. 1996). In this study, foraging experiences had a significant $(P<0.05)$ effect on juniper consumption (Fig. 1). Goats increased intake daily until reaching an apparent toxic threshold on day 5 of each year. Intake dropped thereafter but subsequently increased to levels similar to those recorded on day 5 . Terpene concentrations in juniper are negatively correlated with intake (Riddle et al.
Table 3. Dry matter juniper intake $\left(\mathrm{g} \mathrm{kg}^{-1}\right.$ BW) for offspring in 1998 that were selected as sires in 2000. These 6 individuals were offered 200 $\mathrm{g}$ of juniper daily for 2 hours for 10 days in both years. Sires were classified as the 3 sires that ate the most (Treatment 1) or least (Treatment 2) juniper in 1998. Intake across offspring in 1998 and sires in 2000 was similar $(P>0.05)$.

\begin{tabular}{|c|c|c|c|c|}
\hline Sire & Intake (1998) & SEM & Intake (2000) & SEM \\
\hline \multicolumn{5}{|c|}{ Treatment 1} \\
\hline 13 & 6.1 & 1.05 & 6 & 1.05 \\
\hline 14 & 5.6 & 1.54 & 5.4 & 1.56 \\
\hline 15 & 4.9 & 0.85 & 4.8 & 0.85 \\
\hline \multicolumn{5}{|c|}{ Treatment 2} \\
\hline 16 & 1.8 & 0.38 & 1.7 & 0.4 \\
\hline 17 & 0.8 & 0.15 & 0.6 & 0.17 \\
\hline 18 & 1 & 0.2 & 0.8 & 0.23 \\
\hline
\end{tabular}

1996). As intake increases, goats experience aversive postingestive feedback from overconsumption of terpenoids and decrease intake accordingly (Pritz et al. 1997). Apparently intake levels on day 5 were sufficient to induce aversive postingestive feedback and a subsequent decrease in intake.

This study and others (Bisson et al. 2001; Dunson et al., unpublished data, 2004) have illustrated that goats will increase intake of juniper when it is fed at weaning. Weaning is an important time in the development of feeding preferences because of the loss of maternal influences (Hinch et al. 1987; Howery et al. 1997, 1998). Exposure to juniper before weaning may occur before rumen development, and cause liver and kidney damage (Pritz et al. 1997). Young or immature goats (i.e., preweaning) may lack the digestive and physiological capabilities to detoxify and excrete the terpenoids in juniper, which may result in long-term tissue damage and a decreased ability to consume juniper. When alternative forages are limited, forcing goats to consume excessive amounts of juniper should be delayed until after weaning to allow for adequate physiological development.

\section{MANAGEMENT IMPLICATIONS}

The purpose of this study and others (Riddle et al. 1996; Pritz et al. 1997; Bisson et al. 2001) was to understand the mechanisms controlling juniper intake so that goat foraging behavior could be manipulated to increase juniper acceptance. Specifically, this study addressed the influence of sires on their offspring's acceptance of juniper. On the basis of the data from this study, heritability of juniper consumption appears to be low. However, both male and female goats will increase juniper consumption during pen feeding (Bisson et al. 2001). Replacement females are usually penned and hand-fed during weaning. Producers could hand-cut and feed juniper branches during this time to increase subsequent juniper intake on pasture.

\section{ACKNOWLEDGMENTS}

The authors acknowledge Robert Moen, Terry Brooks, and Sue Engdahl for their assistance with this study. 


\section{LITERATURE CITED}

Ansley, R. J., W. E. Pinchak, and D. N. Ueckert. 1995. Changes in redberry juniper distribution in Northwest Texas. Rangelands 17:49-53.

ARCHER, S. 1994. Woody plant encroachment into southwestern grasslands and savannas: rates, patterns and proximate causes. In: M. Vavra, W. Laycock, and R. Pieper [eds.]. Ecological implications of herbivory in the West. Denver, CO: Society for Range Management. p 36-68.

Bisson, M. G., C. B. Scott, and C. A. Taylor, JR. 2001. Activated charcoal and experience affect intake of juniper by goats. Journal of Range Management 54:274-278.

Bryant, F. C. 1977. Botanical and nutritive content in diets of sheep, Angora goats, Spanish goats and white-tailed deer grazing a common pasture [dissertation]. College Station, TX: Texas A\&M University. $92 \mathrm{p}$.

Bryant, F. C., G. K. Launchbaugh, and B. H. Koerth. 1983. Controlling mature ashe juniper in Texas with crown fires. Journal of Range Management 36:165-168.

Distel, R. D., and F. D. Provenza. 1991. Experience early in life affects voluntary intake of blackbrush by goats. Journal of Chemical Ecology 17:431-450.

Distel, R. D., J. J. Villalba, H. E. Laborde, and M. A. Burgos. 1996. Persistence of the effects of early experience on consumption of low-quality roughage by sheep. Journal of Animal Science 74:965-968.

Dye, K. L., II, D. N. Ueckert, and S. G. Whisenant. 1995. Redberry juniperherbaceous understory interactions. Journal of Range Management 48:100-107.

ElLIS, D., AND J. L. SCHuster. 1968. Juniper age and distribution in an isolated butte in Garza County, Texas. Southwestern Naturalist 13:343-348

Frost, R. A., C. B. Scott, J. W. Walker, and F. S. Hartmann. 2003. Effects of origin, genetics, and experiences early in life on bitterweed consumption by sheep. Applied Animal Behaviour Science 84:251-264.

Griffiths, A. J. F., W. M Gelbart, J. H. Miller, and R. C. Lewontin. 1999. Quantitative genetics. Modern genetic analysis. New York, NY: W.H. Freeman and Co. p 575-606.

Hinch, G. N., E. Lecrivian, J. J. Lynch, and R. L. Elwin. 1987. Changes in maternal young associations with increasing age of lambs. Applied Animal Behaviour Science 17:305-318.

Howery, L. D., F. D. Provenza, R. E. Banner, and C. B. Scott. 1997. Differences in home range and habitat use among individuals in a cattle herd. Applied Animal Behaviour Science 49:305-320.

Howery, L. D., F. D. Provenza, R. E. Banner, and C. B. Scott. 1998. Social and environmental factors influence cattle distribution on rangelands. Applied Animal Behaviour Science 55:231-244.

Johnson, P., A. Gerbolini, D. Ethridge, C. Britton, and D. Ueckert. 1999. Economics of redberry juniper control in the Texas rolling plains. Journal of Range Management 52:569-574.

NelLe, S. 1997. A holistic perspective on juniper. In: C. A. Taylor [ed.]. Proc. Juniper Symposium. San Angelo, TX. Texas Agricultural Experiment Station Technical Report 97-1. p 4.3-4.8

NRC. 1981. Nutrient requirements of goats: Angora, dairy, and meat goats in temperate and tropical countries. Washington, DC: National Academy Press. $p 10$.

Olson, B. E., R. T. Wallander, B. M. Thomas, and R. W. Kott. 1996. Effect of previous experience on sheep grazing leafy spurge. Applied Animal Behaviour Science 50:161-176.

Owens, M. K., C. Lin, C. A. Taylor, JR., and S. G. Whisenant. 1998. Seasonal patterns of plant flamability and monoterpenoid content in Juniperus ashei. Journal of Chemical Ecology 24:2115-2129.

Pritz, R. K., K. L. Launchbaugh, and C. A. Taylor, JR. 1997. Effects of breed and dietery experience on juniper consumption by goats. Journal of Range Management 50:600-606.

ProvenzA, F. D. 1995. Postingestive feedback as an elementary determinant of food preferences and intake in ruminants. Journal of Range Management 48:2-17.

Rasmussen, G. A., AND H. A. Wright. 1989. Succession of secondary shrubs on ashe juniper communities after dozing and prescribed burning. Journal of Range Management 42:295-298.

Riddle, R. R., C. A. Taylor, JR., M. M. Kothmann, and J. E. Huston. 1996. Volatile oil contents of ashe and redberry juniper and its relationship to preference by Angora and Spanish goats. Journal of Range Management 49:35-41.

SAS InStITUTE Inc. 1998. SAS/STAT User's Guide. Version 6.03. Cary, NC: SAS Institute Inc. p 123-138.

Snowder, G. D., J. W. Walker, K. Launchbaugh, and L. D. Van Vleck. 2001. Genetic and phenotypic parameters for dietary selection of mountain big sagebrush in Rambouillet sheep. Journal of Animal Science 79:486-492.

Steuter, A. A., AND C. M. BRITTON. 1983. Fire-induced mortality of redberry juniper [Juniperus pinchotii Sudw.]. Journal of Range Management 36:343-345.

Straka, E., C. B. Scott, C. A. Taylor, JR., and E. M. Bailey. 2003. Biological control of the toxic shrub juniper. $I n$ : T. Acamovic [ed.]. Poisonous plants and related toxins. Oxon, Oxford, UK: CABI Publishing. Ch. 65.

WALKER, J. W. 1995. Viewpoint: grazing management and research now and in the next millennium. Journal of Range Management 48:350-357.

Walker, J. W., K. G. Hemenway, P. G. Hatfield, and H. A. Glimp. 1992. Training lambs to be weed eaters: studies with leafy spurge. Journal of Range Management 45:245-249.

Warren, L., M. Shelton, D. N. Ueckert, and G. D. Snowder. 1983. Influence of heredity on the selection of various forage species by goats. Texas Agricultural Experiment Station CPR 4171. p 72-81. 